\title{
Passive tracers in a general circulation model of the Southern Ocean
}

\author{
I. G. Stevens, D. P. Stevens \\ School of Mathematics, University of East Anglia, Norwich, NR4 7TJ, UK \\ Received: 2 June 1998 / Revised: 22 January 1999 / Accepted: 12 February 1999
}

\begin{abstract}
Passive tracers are used in an off-line version of the United Kingdom Fine Resolution Antarctic Model (FRAM) to highlight features of the circulation and provide information on the inter-ocean exchange of water masses. The use of passive tracers allows a picture to be built up of the deep circulation which is not readily apparent from examination of the velocity or density fields. Comparison of observations with FRAM results gives good agreement for many features of the Southern Ocean circulation. Tracer distributions are consistent with the concept of a global "conveyor belt" with a return path via the Agulhas retroflection region for the replenishment of North Atlantic Deep Water.
\end{abstract}

Key words. Oceanography: general (numerical modeling; water masses) - Oceanography: physical (general circulation).

\section{Introduction}

The Southern Ocean is of particular importance to the global climate as it provides the major connection between the Atlantic, Pacific and Indian Oceans. Of special interest is the heat balance and in addition, the formation and transport of water masses. These and other aspects of the Southern Ocean such as the basic dynamic balance of the Antarctic Circumpolar Current (ACC) are still not well understood. Accordingly, the United Kingdom Fine Resolution Antarctic Model (FRAM) was set up as a community project to investigate these issues. By using a partially eddy resolving grid the performance of the model is considerably improved over existing models. The FRAM results are generally in good qualitative agreement with

Correspondence to: I. G. Stevens observations (FRAM Group, 1991; Lutjeharms and Webb, 1995; Stevens and Killworth, 1992).

A global thermohaline circulation, likened to a conveyor belt involves the circulation of North Atlantic Deep Water (NADW) which moves southwards through the Atlantic Ocean as a deep western boundary current and joins the ACC. This is then the source of deep equatorward flows into the Indian and Pacific Oceans. The replenishment of NADW is via a "warm water path" (Gordon, 1986) in which warm surface water from the Pacific Ocean moves westwards through the Indonesian archipelago into the Indian Ocean and thence by the Agulhas Current into the Atlantic Ocean. An alternative "cold water path" to the Atlantic Ocean (Rintoul, 1991) involves intermediate level water moving southwards from the Pacific Ocean, becoming entrained in the eastwards flowing ACC and passing through the Drake Passage to join the Atlantic Ocean circulation. More recently, Gordon et al. (1992) have suggested a return path via the Drake Passage and Agulhas region. Here water initially takes the "cold water path" but then enters the Indian Ocean to gain heat before entering the Atlantic Ocean.

Tracers such as temperature, salinity, oxygen and nutrients have long been used in deducing the pattern of ocean circulation and the characteristics of mixing processes. More recently, transient tracers such as CFCs, radiocarbon, tritium and ${ }^{3} \mathrm{He}$ have also been employed (Toggweiler et al., 1989; England, 1995b; Sarmiento, 1983). In a numerical model idealised passive tracers can be introduced and their movement followed in order to highlight the flow field, particularly in the deep ocean where the circulation is slow (Cox, 1989; Stocker et al., 1992; England, 1995a). The movement of water masses is traditionally determined by following a characteristic temperature or salinity signature. This signature is gradually lost by mixing. If a passive tracer is used to follow a water mass the signal degrades through mixing but remains visible compared to the surrounding water.

In order to fully represent the effect of eddy transports one would like to calculate the tracer evolution synchro- 
nously with the model. The FRAM integration, which stretched available computing resources to the limit was carried out for a total of 15 model years. At the end of this period the model is close to dynamic equilibrium rather than thermodynamic equilibrium. However the density field is close to climatology and the model velocity field contains useful information (Saunders and Thompson, 1993). To follow tracers in the deep ocean requires long integrations and therefore integrating the tracer equation alone is carried out using a specified time independent velocity field from the main FRAM run. Because the method used here solves only the tracer equation it involves considerably less computational effort than solving the full set of equations. Relatively long integrations can therefore be performed which allows visualisation of the slow deep circulation. By an appropriate choice of source location for the tracer particular features of the circulation can be studied.

\section{Model equation}

FRAM is a three dimensional eddy-resolving primitive equation model based on that of Cox (1984). The domain covered by the model is between $24^{\circ} \mathrm{S}$ and $79^{\circ} \mathrm{S}$. The horizontal grid is $0.5^{\circ}$ in longitude and $0.25^{\circ}$ in latitude. This equates to a grid spacing at $60^{\circ} \mathrm{S}$ of $27 \mathrm{~km}$ which means that the model can be considered eddy permitting. There are 32 vertical levels, the thickness of which varies between $20.7 \mathrm{~m}$ and $233 \mathrm{~m}$. Convection is included by examining the stability of each pair of adjacent vertical levels at each horizontal grid point, and mixing if the water column is unstable. The equations are solved using finite differences on an Arakawa 'B' grid. Further details of the solution method are given by Cox (1984).

FRAM was initialised as a cold $\left(-2{ }^{\circ} \mathrm{C}\right)$, saline (36.69) motionless fluid and slowly relaxed to Levitus (1982) temperature and salinity fields. Wind forcing (Hellerman and Rosenstein, 1983) was added after three years and linearly increased to its steady value over a period of six months. At the end of six years integration the model appeared close to dynamical equilibrium with the forcing fields. During this phase of the run the horizontal and vertical mixing co-efficients for tracers have values $1 \times 10^{2} \mathrm{~m}^{2} \mathrm{~s}^{-1}$ and $0.5 \times 10^{-4} \mathrm{~m}^{2} \mathrm{~s}^{-1}$ respectively. The year 6 dataset, which has been published in atlas form (Webb et al., 1991) consists of the temperature, salinity and velocity fields at an instant in time at the end of the robust diagnostic phase of the model run. The temperature and salinity fields resemble the smooth Levitus (1982) data but with frontal features considerably sharpened. The velocity field shows a banded structure in many areas with eddy activity off South Africa and southeast Australia. The model run was then continued with a four year eddy development phase which included the introduction of bi-harmonic horizontal friction with mixing coefficient $-1 \times 10^{12} \mathrm{~m}^{4} \mathrm{~s}^{-2}$, and no relaxation terms except in the surface level. This was followed by a 6 y intensive analysis phase from years 10 to 15 . During this phase data from the model are archived at monthly intervals. A time average of the 72 datasets provides the velocity field used in this study. This dataset, includes the mean effect of eddies and is from a time when the model interior has been running free of relaxation terms. The temperature and salinity fields are also averaged in a similar way and used to calculate the density field, from which a condition on convective mixing is deduced at each grid point. The convective mask is derived from a mean dataset and does not correctly include the effect of seasonal convection. The surface forcing in FRAM is to annual mean Levitus climatology in which the temperature and salinity observations are biased towards summer observations. The effect of winter convection is thus not fully represented in FRAM itself (Ribbe and Tomczak, 1997). However, here we are concerned mainly with the deep inter-basin exchange which will be little affected by such events.

The equation solved in this study is the FRAM tracer equation with the addition of an ageing term. For a passive tracer $T$ the governing equation is

$$
\begin{aligned}
\frac{\partial T}{\partial t} & +\frac{1}{a \cos \phi} \frac{\partial}{\partial \lambda}(u T)+\frac{1}{a \cos \phi} \frac{\partial}{\partial \phi}(v T \cos \phi)+\frac{\partial}{\partial z}(w T) \\
& =K_{h} \frac{\partial^{2} T}{\partial z^{2}}+A_{h} \nabla^{2} T+B_{h} \nabla^{4} T+1 .
\end{aligned}
$$

The variables $\lambda, \phi, z$ represent longitude, latitude and depth, with corresponding velocity components $u, v, \mathrm{w}$. The radius of the earth is a; $K_{h}, A_{h}$ are vertical and horizontal Laplacian mixing co-efficients respectively, and $B_{h}$ is the horizontal bi-harmonic mixing coefficient. In this study the tracer equation is solved using specified velocity and convective mask.

The passive tracer used is age (Thiele and Sarmiento, 1990). The conventional use of an age tracer would be to initialise the age everwhere to zero then integrate Eq. (1) forwards in time, re-setting the age at the surface to zero. If this method is integrated to equilibrium then the age of any particle is a volume weighted average time since that particle was last at the surface. This method was used by England (1995a) in a coarse resolution global model to simulate the age of deep and bottom water masses. Additional information on the nature of ocean ventilation on decadal to centenial time scales was obtained by introducing a dye tracer at the surface.

In this study we are less concerned with the ventilation process and the age of deep water masses, rather we are using a passive tracer to highlight features of the circulation and determine the inter-basin pathways in a fine resolution model. We therefore choose the source boundary to be a meridional or zonal section rather than the surface. Age in this situation is not used in the conventional sense and cannot be used to determine time scales since water particles were last at the source boundary but can provide useful information on the movement of water masses on centenial time scales. The model of England (1995a) required a run of 4650 y for the age tracer to approach equilibrium. The computing resources needed to run even an off-line tracer model at the FRAM resolution to a similar state are far in excess of those available. However, by initialising the interior age to $200 \mathrm{y}$ and integrating the model for $100 \mathrm{y}$ there is 
sufficient contrast in the age field to highlight many features of the circulation. This represents a balance between model resolution and integration time. A coarse resolution model could be integrated for the required length of time to reach equilibrium but the far greater realism provided by a fine resolution model would be lost. On non-source open boundaries the conditions described by Stevens (1991) are used. The mixing coefficients $K_{h}, A_{h}$ and $B_{h}$ have the same values in this tracer model as in the analysis phase of the FRAM run and given above. FRAM has three open boundaries at $24^{\circ} \mathrm{S}$ in the Atlantic, Indian and Pacific Oceans. These are appropriate as sources for studying the exchange of water between these oceans. The fourth source boundary is chosen as a meridional section spanning the Drake Passage. This provides information about the exchange of ACC water with the other oceans.

Another approach to studying inter-ocean exchange which has been used by Döös (1995) is to examine particle trajectories. Both approaches have advantages and disadvantages and can be seen as complimentary. The particle trajectory approach, which uses the same velocity field from FRAM follows the trajectories of particles introduced at one of the three open boundaries until they exit the model. It is possible to accurately calculate transports by using very many particles $(\sim 5.5$ million). This approach can also determine if a trajectory is ventilated and allows for multiple circuits of Antarctica. The treatment of convection here is however, more consistent with the original FRAM run where the unstable part of the water column is homogenised rather than the particle trajectory approach where convection is ignored.

\section{Presentation of results}

Results are presented as plots of tracer age on zonal sections, horizontal levels and isopycnal surfaces. The open boundary conditions in FRAM are applied at $24^{\circ} \mathrm{S}$ and generally perform very well having little unphysical effect on the nearby interior solution. For instance, a detailed study of the circulation around South Africa (Lutjeharms and Webb, 1995) shows that the open boundary condition behaves well in this highly active region. The zonal sections are presented at $27^{\circ} \mathrm{S}$. This is an appropriate latitude to illustrate the exchange through the open boundaries while being sufficiently far from the boundary to avoid any boundary effects. The horizontal sections are at depths appropriate for the features being discussed. Tracer introduced on the Atlantic Ocean boundary is shown on the isopycnal surface $\sigma_{3}=41.48$ to illustrate the spreading of NADW. The contour levels used for the different sections are not the same. With the restrictions imposed by using only five grey scales for clarity, they are chosen to highlight particular features. Some caution needs to be exercised when interpreting plots of tracer age. In some cases recirculation can give a misleading picture of the flow pattern. However, examination of associated sections can usually clarify the picture. The method described here primarily gives a visual picture of the circulation. Approximate transports may be calculated on meridional or zonal sections by integrating the appropriate velocity component over an area enclosed by a contour of a particular age. The transport obviously depends on the particular age contour chosen. However, in most cases inspection of the velocity field leads to an appropriate choice of age contour. All the results are presented after a $100 \mathrm{y}$ integration. The age of the tracer will therefore be between 0 and $300 \mathrm{y}$. Reference is made to figures from the FRAM atlas (Webb et al., 1991) which are not reproduced here.

\subsection{Atlantic Ocean boundary}

Tracer is introduced at the Atlantic boundary as a zonal slab at $24^{\circ} \mathrm{S}$. The Indian and Pacific Ocean boundaries are left open. A zonal section of tracer age at $27^{\circ} \mathrm{S}$ from South America to South Africa is shown in Fig. 1. The areas of low age indicate water moving southwards away from the source boundary. The area at the surface near $48^{\circ} \mathrm{W}$ represents the Brazil Current. At depths greater than $1400 \mathrm{~m}$ the low age is identified as southward moving north Atlantic Deep Water (NADW). This is concentrated near to the South American slope between $46^{\circ} \mathrm{W}$ and $39^{\circ} \mathrm{W}$ mainly at depths between $1600 \mathrm{~m}$ and $3400 \mathrm{~m}$. There is also some evidence of NADW moving southwards close to the Mid-Atlantic Ridge near $12^{\circ} \mathrm{W}$. Evidence for the southwards flow of NADW at depths greater than $3600 \mathrm{~m}$ on the eastern flank of the Mid-Atlantic Ridge is seen in distributions of aluminium concentration (Measures and Edmond, 1990). A zonal section of salinity at $32.5^{\circ} \mathrm{S}$ (Reid et al., 1977) also indicates a layer of NADW at a depth of $2800 \mathrm{~m}$ extending eastwards from the main western boundary current with an area of increased salinity close to the west flank of the MidAtlantic Ridge. The NADW appears in the FRAM atlas on WOCE section A23 as water with a temperature of $3{ }^{\circ} \mathrm{C}$ and salinity 34.9 . The transport of NADW at $27^{\circ} \mathrm{S}$ within the deep western boundary current is $14 \mathrm{~Sv}$. This compares with $14 \mathrm{~Sv}$ in the western boundary current at $5^{\circ} \mathrm{S}$ of the Semtner and Chervin (1992) global ocean model. The transport associated with the flow close to the Mid-Atlantic Ridge is $2 \mathrm{~Sv}$. One weakness of FRAM is the poor representation of the formation of Antarctic Bottom Water (AABW). This may be due to the lack of seasonal forcing and/or the relatively smooth topography which fills in some of the bottom water pathways (Wadley and Bigg, 1994). Figure 1 indicates a northwards abyssal flow at depths greater than $3500 \mathrm{~m}$ between $4^{\circ} \mathrm{E}$ and $13^{\circ} \mathrm{E}$ in the Cape Basin however there is little evidence of equatorward flowing abyssal water between $40^{\circ} \mathrm{W}$ and $20^{\circ} \mathrm{W}$.

The area of relatively high age between the surface and $600 \mathrm{~m}$, and extending from $5^{\circ} \mathrm{W}$ to the South African coast at $15^{\circ} \mathrm{E}$ is a result of the northwards flowing Benguela Current. This is above a sub-surface countercurrent between $800 \mathrm{~m}$ and $2000 \mathrm{~m}$. The signature of Antarctic Intermediate Water (AAIW) is seen as a layer of 


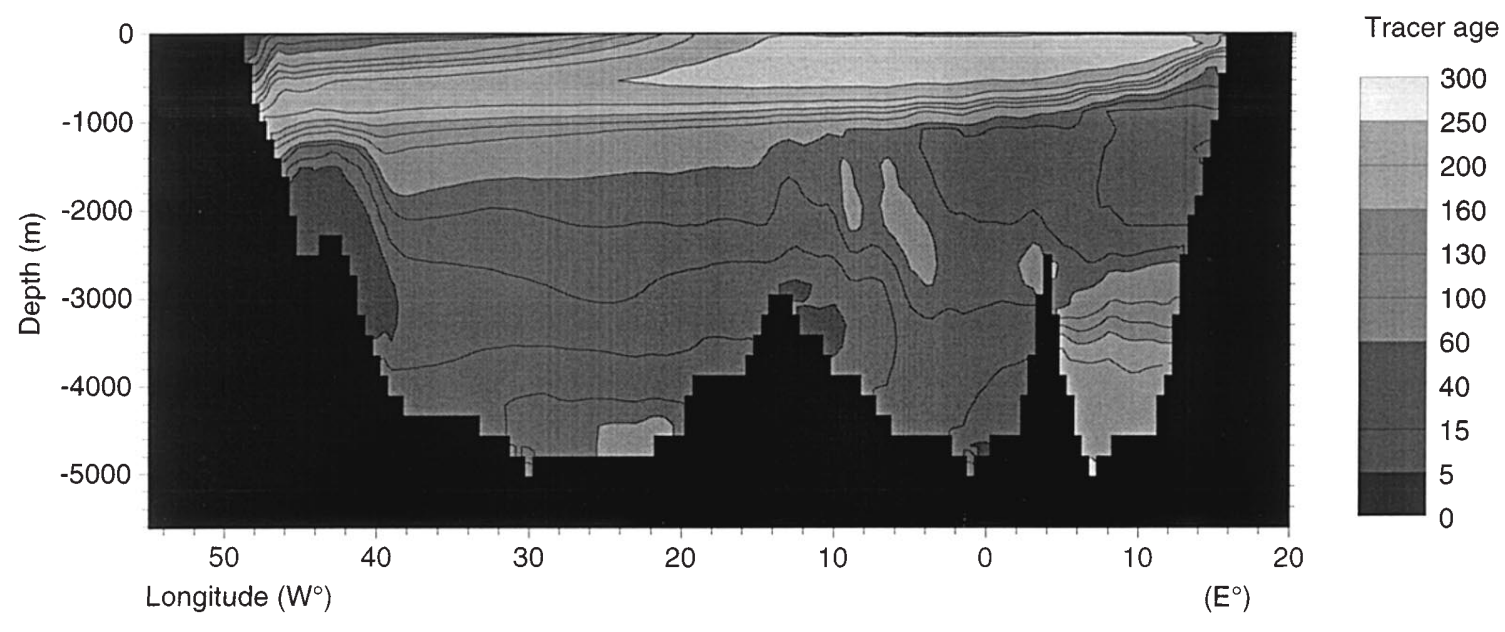

Fig. 1. A zonal section at $27^{\circ} \mathrm{S}$ from South America $\left(50^{\circ} \mathrm{W}\right)$ to South Africa $\left(18^{\circ} \mathrm{E}\right)$, illustrating the age of tracer introduced at the Atlantic Ocean boundary $\left(24^{\circ} \mathrm{S}\right)$

relatively high age at depths around $1000 \mathrm{~m}$ extending across the whole basin. The depth of maximum age of this water reduces as one progresses from west to east across the basin. A zonal section of salinity along $30^{\circ} \mathrm{S}$ (Siedler et al., 1993) shows AAIW as a salinity minimum shallowing by $300 \mathrm{~m}$ from west to east.

Figure $2 \mathrm{a}$ shows the age of tracer on the density surface $\sigma_{3}=41.48$, and Fig. $2 \mathrm{~b}$ the corresponding depth of that surface. The NADW moves southwards along the western boundary separating at around $40^{\circ} \mathrm{S}$ and moving eastwards with the ACC, crossing the Greenwich meridian at $43^{\circ} \mathrm{S}$, and following the ACC around Antarctica to the Drake Passage. Tracer is taken into the Indian Ocean directly through the Mozambique Channel at $40^{\circ} \mathrm{E}$ and also via the Crozet Basin at $50^{\circ} \mathrm{E}$. The flow into the Mozambique Channel is unrealistic and is discussed further in the Sect. 3.3. The NADW carried along with the ACC mainly passes to the north of the Kerguelen Plateau at $75^{\circ} \mathrm{E}, 50^{\circ} \mathrm{S}$ (Mantalya and Reid, 1995) and enters the Pacific Ocean to the east of Australia. Horizontal sections at greater depths also indicate NADW entering the Pacific Ocean as a deep western boundary current to the east of the TongaKermadec Ridge along $170^{\circ} \mathrm{W}$ at depths greater than $3600 \mathrm{~m}$. The increase in density of this water may be due to mixing with AABW (Döös, 1995).

Figure $2 b$ indicates that on leaving the South American coast at $40^{\circ} \mathrm{S}$ the tracer is at a depth of $2600 \mathrm{~m}$ but gradually rises as it circles Antarctica such that it is at a depth of $1700 \mathrm{~m}$ passing through the Drake Passage. This is in accordance with the particle trajectory approach of Döös (1995). Furthermore, using a global ocean model Döös and Coward (1997) find that approximately $60 \%$ of NADW upwells in the Southern Ocean south of $50^{\circ} \mathrm{S}$.

\subsection{Pacific Ocean boundary}

Tracer is introduced along the Pacific boundary on a zonal slab at $24^{\circ} \mathrm{S}$. The Atlantic and Indian Ocean boundaries are open in this case. A zonal section of tracer age at $27^{\circ} \mathrm{S}$ from Australia to South America is shown in Fig. 3. A feature of Fig. 3 is the basin-wide southwards transport of surface water between the Australian coast at $155^{\circ} \mathrm{E}$ and $100^{\circ} \mathrm{W}$. The old nearsurface tracer between $100^{\circ} \mathrm{W}$ and the South American coast at $70^{\circ} \mathrm{W}$ represents the equatorward Humboldt Current which is above the poleward subsurface Gunther Current. This pattern of eastern boundary currents is similar to those seen for the Atlantic Ocean. The signature of AAIW is also seen with its mean depth increasing to the west, again in accordance with WOCE section P6 in the FRAM atlas (Webb et al., 1991).

The low tracer age between the surface and $2500 \mathrm{~m}$ near $155^{\circ} \mathrm{E}$ indicates a southwards flowing western boundary current and is identified as the East Australia Current. Velocity measurements suggest that the current extends to at least $2300 \mathrm{~m}$ (Boland and Hamon, 1970) and more recently, Mulhearn et al. (1986) observed a strong correlation between the deep structure and the surface flows.

Stommel et al. (1973) observed a deep narrow western boundary current flowing northwards along the Tonga-Kermadec Ridge at $176^{\circ} \mathrm{W}$, and also suggested a slow northwards flow between $3000 \mathrm{~m}$ and the bottom extending much further to the east. Above this a southwards flow removed from the Tonga-Kermadec ridge occurs at depths between $2000 \mathrm{~m}$ and $3000 \mathrm{~m}$. The pattern of tracer age in Fig. 3 suggests the same circulation. A zonal section at $32.5^{\circ} \mathrm{S}$, WOCE Section P6, (Banks et al., 1995) indicates Pacific Deep water (PDW) moving southwards at a mean depth of $2800 \mathrm{~m}$ above equatorward moving Lower Circumpolar Deep Water (LCDW). The boundary between the contra flowing water masses is at the level of the $1.2{ }^{\circ} \mathrm{C}$ isotherm and meets the Tonga-Kermadec Ridge at a depth of $3000 \mathrm{~m}$. The transports deduced by Banks et al. (1995) are $14.2 \mathrm{~Sv}$ for the northwards flowing LCDW and 2.9 Sv for the southwards flowing PDW. The velocity field from FRAM gives values of $5 \mathrm{~Sv}$ and 2.9 Sv respectively. The values calculated by Banks et al. 

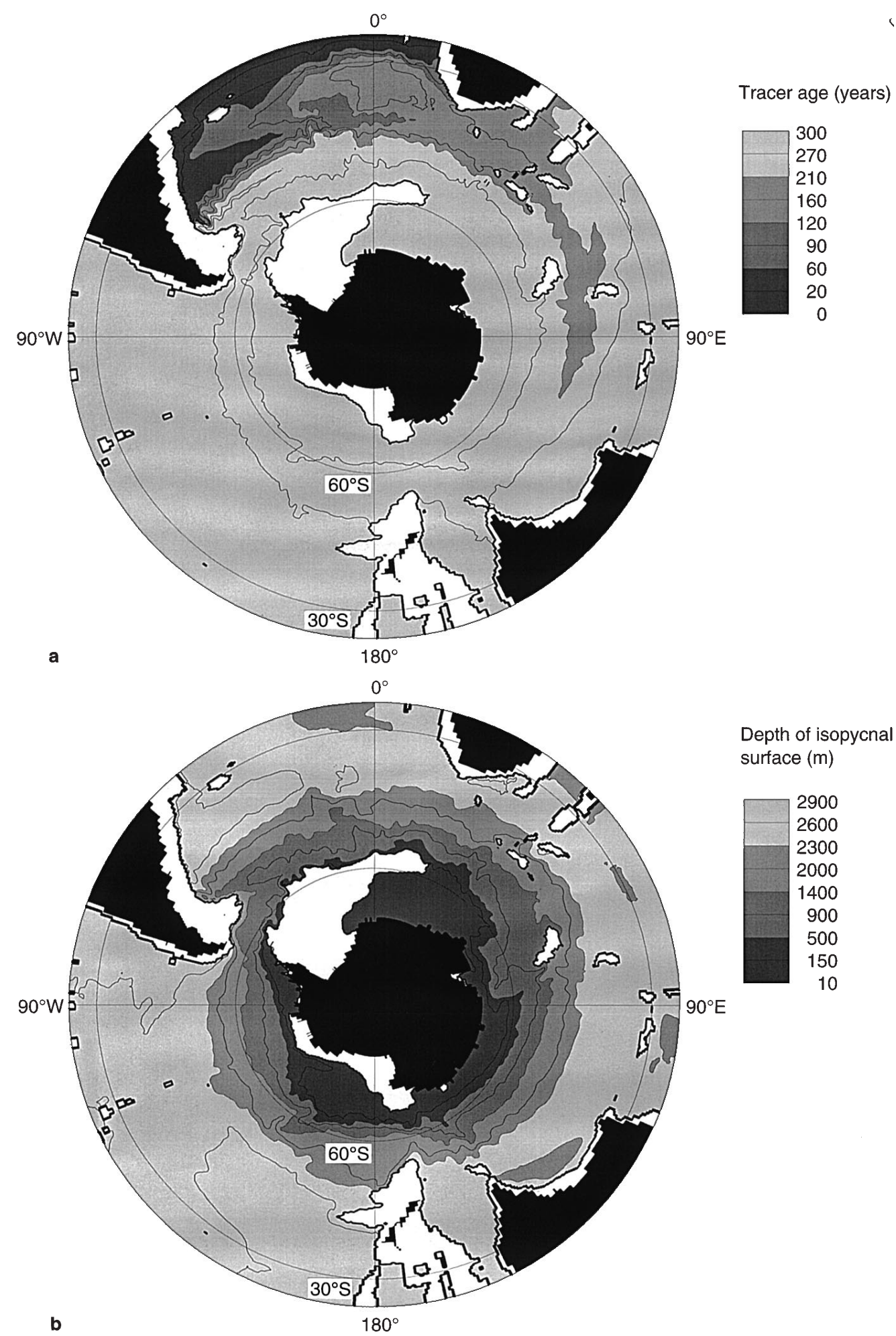

Fig. 2. a A section on $\sigma_{3}=41.48$ illustrating the age of tracer introduced at the Atlantic Ocean boundary $\left(24^{\circ} \mathrm{S}\right)$ b The depth of the $\sigma_{3}=41.48$ surface

(1995) are obtained by summing the transports for $0.1{ }^{\circ} \mathrm{C}$ temperature classes and the major contribution to the northwards transport of LCDW comes from water cooler than $0.65^{\circ} \mathrm{C}$. Water less than this temperature does not exist in FRAM in this region. However, using data from Banks et al. (1995), for LCDW between $0.65^{\circ} \mathrm{C}$ and $1.2^{\circ} \mathrm{C}$ the northwards transport is $4.5 \mathrm{~Sv}$, much closer to the value from FRAM and again this is another indication that the northwards flowing AABW is poorly represented in FRAM.

The age of tracer at a depth of $1087 \mathrm{~m}$ is shown in Fig. 4. The strong poleward flow of the East Australia Current at $155^{\circ} \mathrm{E}$ is seen to move around Tasmania and westwards into the Indian Ocean. The westwards transport of this current at $146^{\circ} \mathrm{E}$ is $4 \mathrm{~Sv}$. Fine (1993) suggests such a pathway is consistent with salinity, 


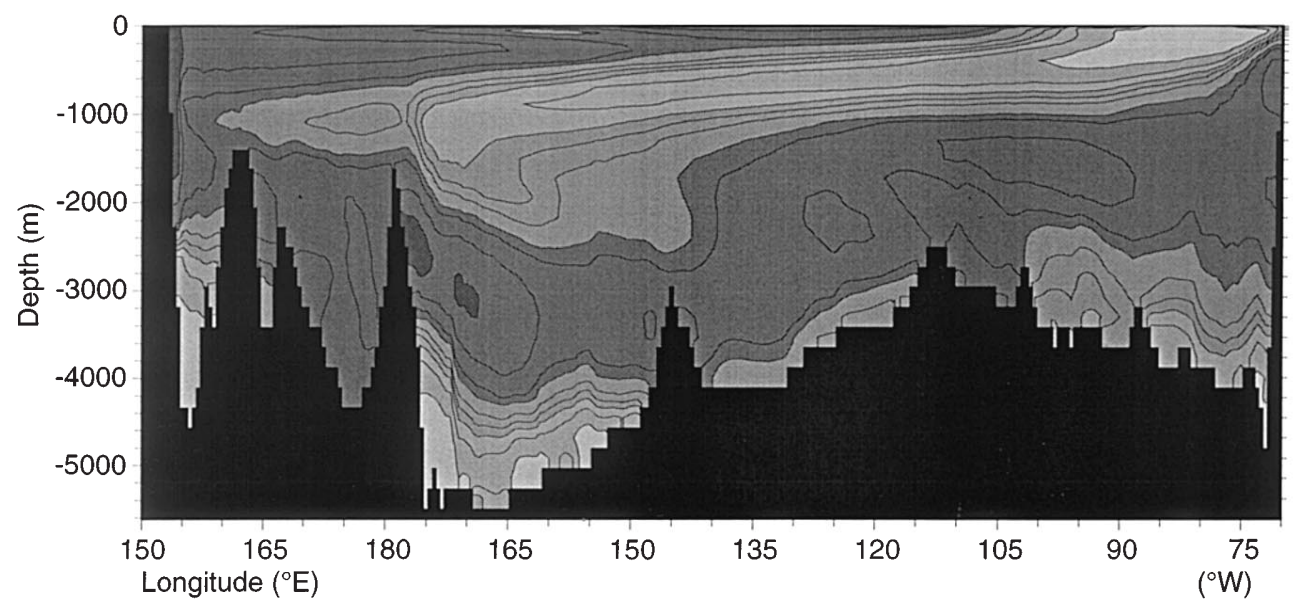

Tracer age (years)

Fig. 3. A zonal section at $27^{\circ} \mathrm{S}$ from Australia $\left(150^{\circ} \mathrm{E}\right)$ to South America $\left(70^{\circ} \mathrm{W}\right)$, illustrating the age of tracer introduced at the Pacific Ocean boundary $\left(24^{\circ} \mathrm{S}\right)$

oxygen and CFC concentrations in the Southwest Indian Ocean. Water is also taken from the East Australia current at $\sim 33^{\circ} \mathrm{S}$, eastwards to the north of New Zealand, before continuing eastwards along $45^{\circ} \mathrm{S}$ to the north of the ACC. The separation of the East Australia Current has been observed by Mulhearn (1988) and is also clearly seen in the Semtner and Chervin (1992) model results. There is also a weak poleward flow close to South America with a general equatorward flow of AAIW across the width of the Pacific. Also evident is a westwards flow to the north of New Zealand, almost reaching the Australian coast at $28^{\circ} \mathrm{S}$.

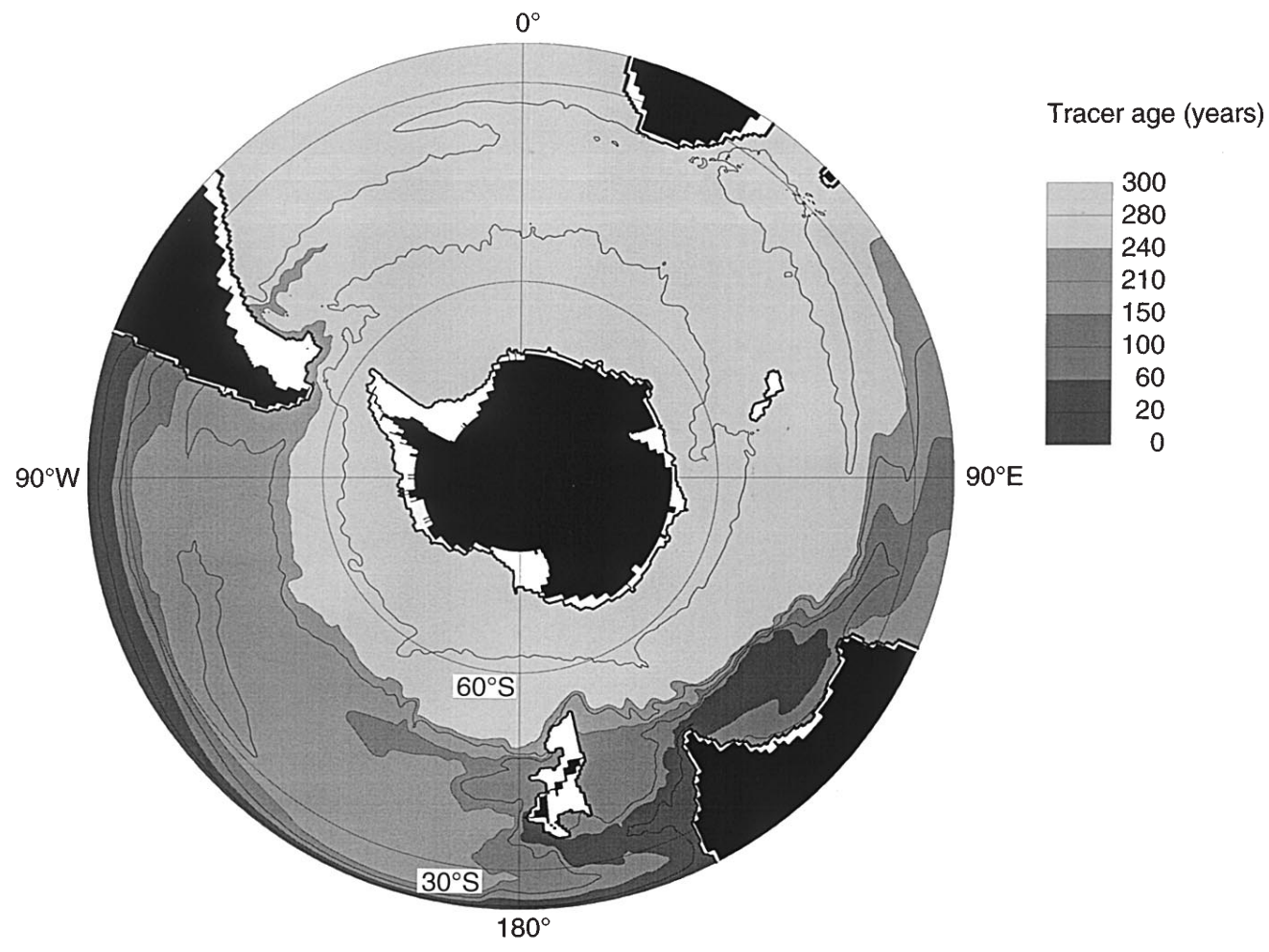

\subsection{Indian Ocean boundary}

Here tracer is introduced on a zonal slab at $24^{\circ} \mathrm{S}$ along the Indian Ocean boundary. The Atlantic and Pacific Oceans are open in this case. A zonal section of tracer age at $27^{\circ} \mathrm{S}$ between South Africa and Australia is shown in Fig. 5. The path of abyssal water northwards from the Weddell Sea towards the Indian Ocean follows two major routes: (1) through a gap in the SW Indian Ridge at $30^{\circ} \mathrm{E}, 50^{\circ} \mathrm{S}$; and (2) via the Crozet Basin and a gap in the SW Indian Ridge at $60^{\circ} \mathrm{E}, 30^{\circ} \mathrm{S}$ to the Madagascar Basin. The route north through the Mozambique Basin is blocked by the shallow Mozambique
Fig. 4. A horizontal section at $1087 \mathrm{~m}$ illustrating the age of tracer introduced at the Pacific Ocean boundary $\left(24^{\circ} \mathrm{S}\right)$ 


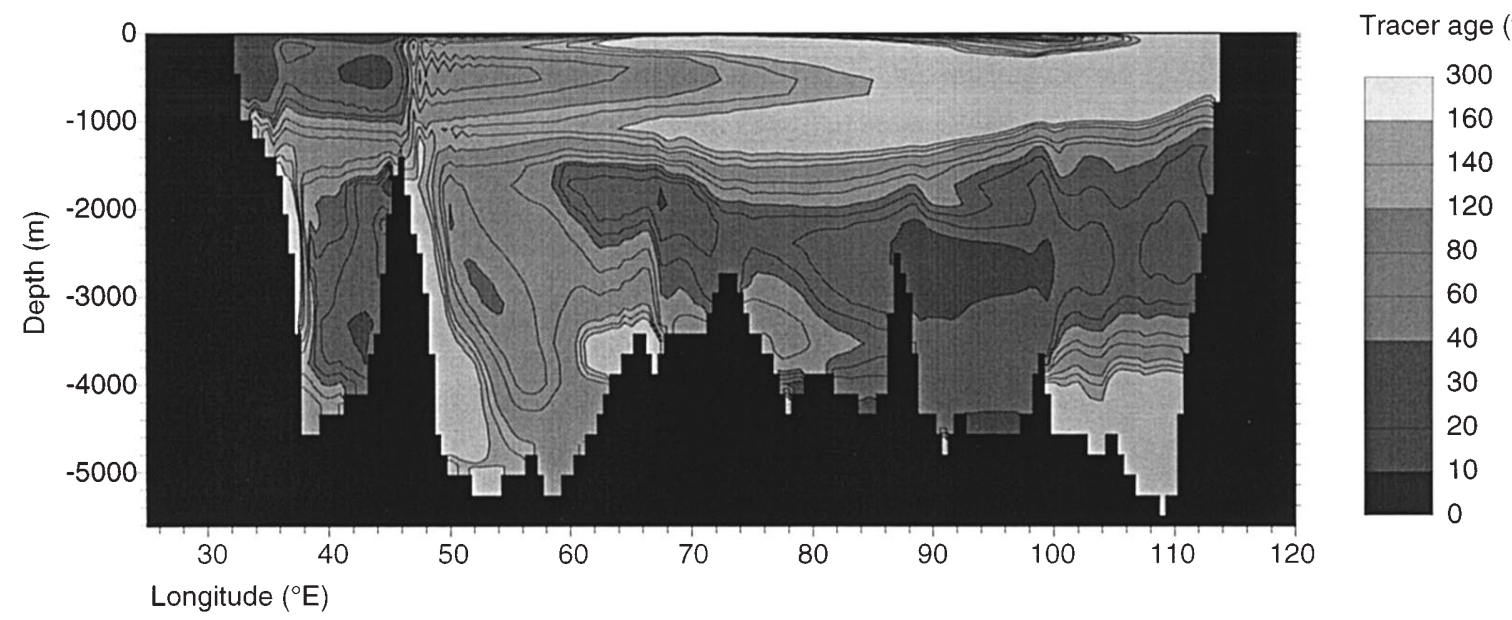

Fig. 5. A zonal section at $27^{\circ} \mathrm{S}$ from South Africa $\left(30^{\circ} \mathrm{E}\right)$ to Australia $\left(115^{\circ} \mathrm{E}\right)$, illustrating the age of tracer introduced at the Indian Ocean boundary $\left(24^{\circ} \mathrm{S}\right)$

Channel, however because the model boundary is at $24^{\circ} \mathrm{S}$, FRAM allows abyssal water to flow northwards between Africa and Madagascar. The tracer distribution in Fig. 5 shows an equatorward flowing deep western boundary current extending from $2000 \mathrm{~m}$ to $5000 \mathrm{~m}$ on the western boundary of the Madagascar Basin at $50^{\circ} \mathrm{E}$ and a poleward counter-current further east at depths around $3000 \mathrm{~m}$. Evidence of an offshore counter-current to the east of Madagascar is presented by Mantalya and Reid (1995). The equatorward western boundary current and offshore counter-current in the Mozambique Channel is due to the geographical boundary of FRAM mentioned earlier.

The deep Indian Ocean is also open to the south just west of Australia, and observations at $18^{\circ} \mathrm{S}$ (Warren, 1977) suggests that deep water which enters here flows northwards on the east flank of the Ninetyeast Ridge. Due to its geographic limits, FRAM includes only the southernmost end of the Ninetyeast Ridge. However, no deep equatorward current is seen even on sections at $25^{\circ} \mathrm{S}$ and Fig. 5 shows a southwards current around the Ninetyeast Ridge. There is some suggestion of an equatorward abyssal current at depths greater than $4000 \mathrm{~m}$ around $105^{\circ} \mathrm{E}$. The deficiency in the production of abyssal water in sufficient quantities in FRAM may contribute to the poor representation of the deep Indian Ocean circulation.

The age of tracer introduced at the Indian Ocean boundary is shown at a depth of $532 \mathrm{~m}$ in Fig. 6. Tracer derived from the Agulhas retroflection zone moves eastwards and develops into a narrow jet between the ACC and the westwards flowing continuation of the East Australia Current. It then continues eastwards to the south of New Zealand, across the Pacific Ocean and through the Drake Passage. Tracer is also transported northwestwards from the retroflection zone into the Atlantic Ocean. Some of the Indian Ocean tracer which enters the Atlantic Ocean reaches the coast of South America and is brought southwards in the Brazil Current, separating at $38^{\circ} \mathrm{S}$ and moving eastwards in the subtropical gyre.

\subsection{Drake Passage section}

In this case tracer is introduced on a meridional slab at a longitude of $71^{\circ} \mathrm{W}$ spanning the Drake Passage. The open boundary condition is applied at $24^{\circ} \mathrm{S}$ in the other oceans. To illustrate the transport of water from the ACC into the Atlantic, Indian and Pacific Oceans a zonal section of tracer age at $27^{\circ} \mathrm{S}$ is shown in Fig. 7 . Because the source boundary is to the south of this section the areas of low age indicate northwards flowing currents. Some aspects of the circulation described previously are evident, in particular the equatorward flow to the east of the Tonga-Kermadec Ridge at $175^{\circ} \mathrm{W}$. The near surface flows into the Pacific and Atlantic Oceans are on the eastern boundary and have transports of $7 \mathrm{~Sv}$ and $6 \mathrm{~Sv}$ respectively. The equatorwards flow into the Indian Ocean occurs across the whole width of the basin but is enhanced in the middle one third. The transport here is $7 \mathrm{~Sv}$. Further features of the near surface circulation are revealed from the horizontal section of tracer age at a depth of $120 \mathrm{~m}$ shown in Fig. 8. This level is chosen as being representative of the near surface circulation with similar results down to $500 \mathrm{~m}$. The path of the ACC is evident with a sharp front at around $38^{\circ} \mathrm{S}, 45^{\circ} \mathrm{W}$ indicating the BrazilFalkland Current confluence. It is clear that the majority of the equatorward transport of water at this depth is into the Indian Ocean and that water does not enter the Atlantic Ocean directly from the ACC but via the Indian Ocean. This supports the view of Gordon et al. (1992) of a modified cold water path. The route taken by water from the ACC into the Pacific Ocean lies close to South America suggesting that water fron the ACC is the source of the equatorward Humbolt Current. This section also illustrates the extent of the Ross Sea gyre centred on $155^{\circ} \mathrm{W}, 70^{\circ} \mathrm{S}$ and the Weddell Sea gyre extending from $70^{\circ} \mathrm{W}$ to $45^{\circ} \mathrm{E}$ along $65^{\circ} \mathrm{S}$.

A horizontal section at a depth of $1945 \mathrm{~m}$ in Fig. 9 shows a clear front along both sides of the ACC in the Atlantic Ocean. At this depth it appears that a substantial part of the ACC is blocked by the Kerguelen 


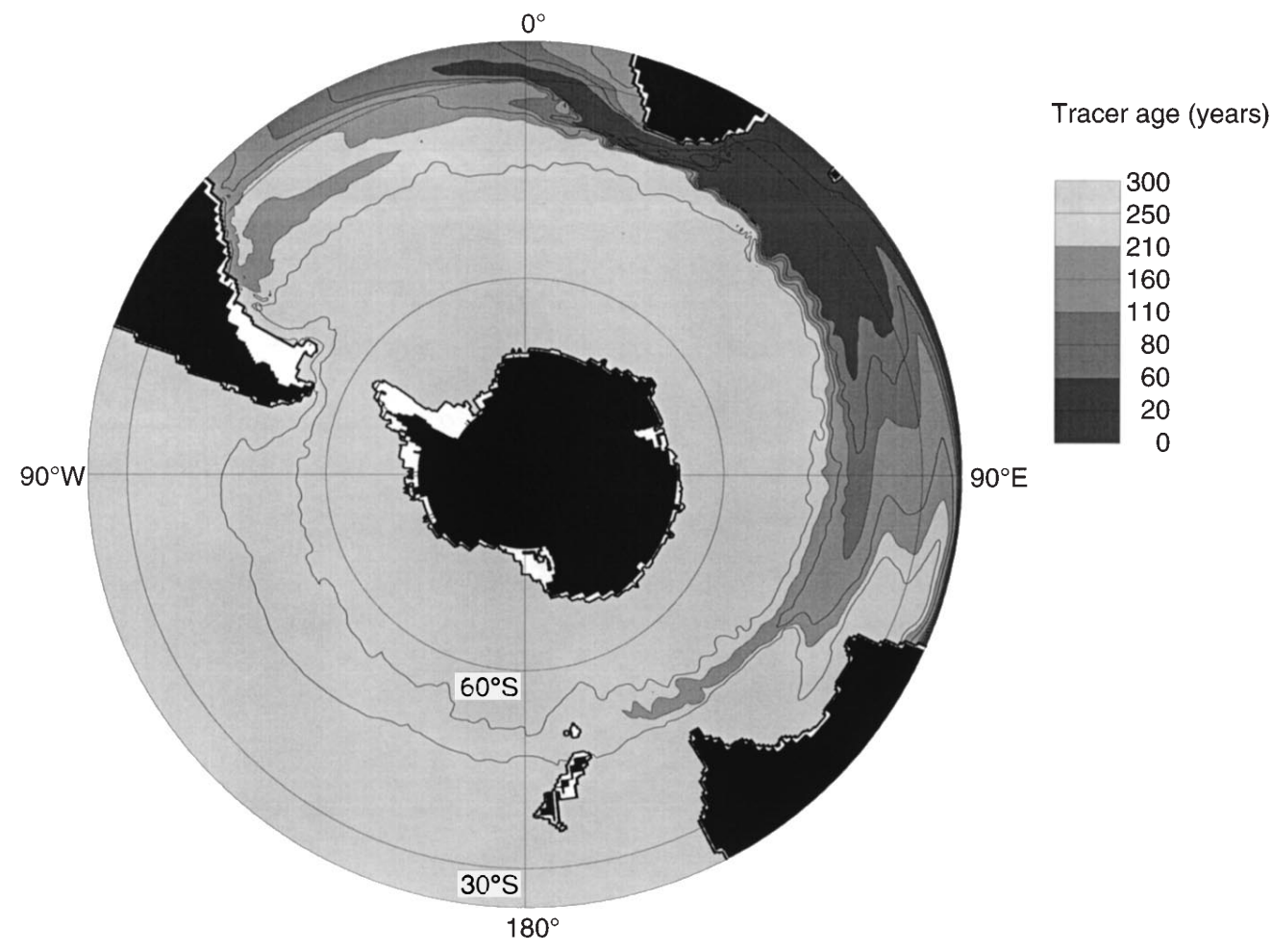

Fig. 6. A horizontal section at $532 \mathrm{~m}$ illustrating the age of tracer introduced at the Indian Ocean boundary $\left(24^{\circ} \mathrm{S}\right)$
Ridge and forced southwards. Some water moves eastwards to the south of the Kerguelen Ridge at $85^{\circ} \mathrm{E}, 65^{\circ} \mathrm{S}$ and the remainder travels westwards into the Weddell Gyre. Sections of Atlantic Ocean tracer (and Fig. 2a, b) indicate that the eastwards flow to the north of Kerguelen, at this depth, is composed mainly of NADW. The Ross Sea gyre is also evident in this section.

At $112^{\circ} \mathrm{W}$ water is taken northwards from the ACC into the Pacific Ocean reaching $36^{\circ} \mathrm{S}$. This effect which occurs at depths between $1200 \mathrm{~m}$ and $2500 \mathrm{~m}$ and is situated directly above the crest of the East Pacific Rise. The transport associated with this flow at $47^{\circ} \mathrm{S}$, just after it separates from the ACC is however only $0.3 \mathrm{~Sv}$.

\subsection{Inter-basin transport}

To illustrate the inter-basin exchanges of water, schematic meridional sections of tracer age have been produced at $20^{\circ} \mathrm{E}$, South Africa to Antarctica; $146^{\circ} \mathrm{E}$, Tasmania to Antarctica; and $71^{\circ} \mathrm{W}$ the Drake Passage. These lines of longitude roughly define the three oceans, and the sections provide a picture of the water exchange between them. The schematic pictures have been built up from sections of tracer age and the labelled areas indicate where water is predominately from one source. The remainder of the sections are areas where the currents are generally weak and do not contribute to the major pathways of inter-basin exchange. All areas

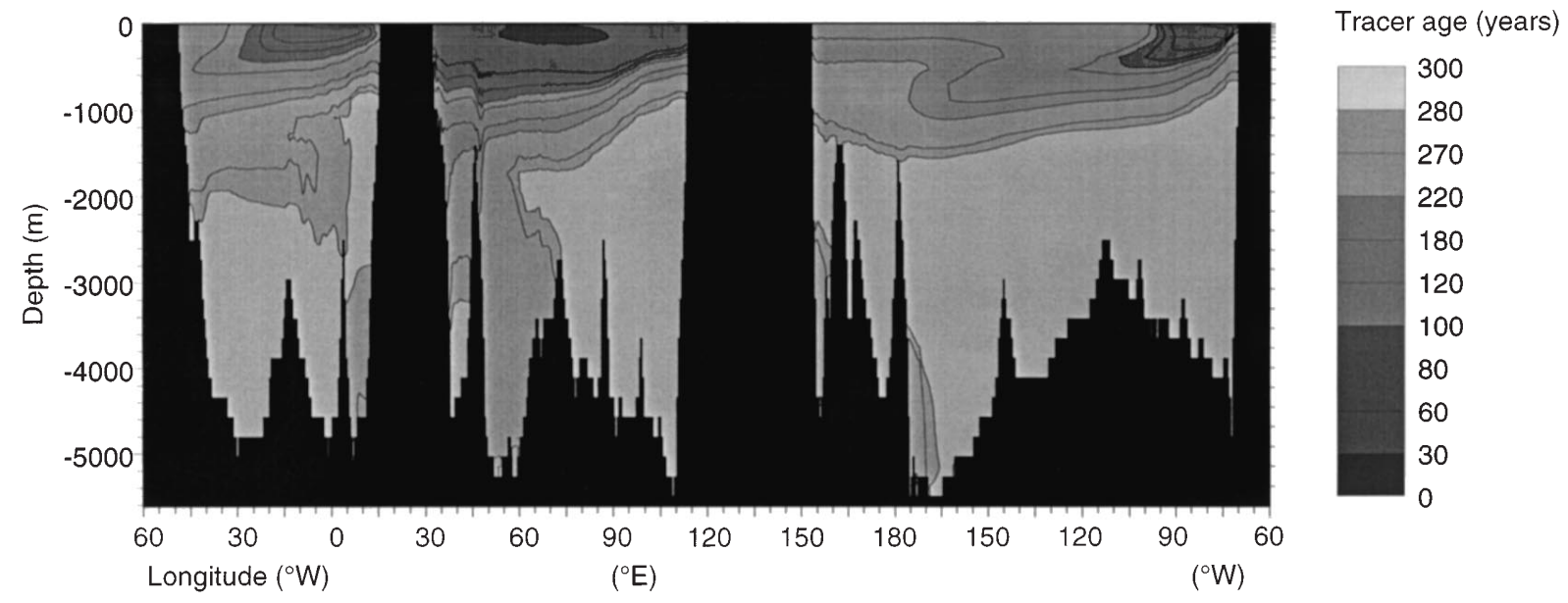

Fig. 7. A zonal section at $27^{\circ} \mathrm{S}$ circling the globe illustrating the age of tracer introduced at the Drake Passage $\left(71^{\circ} \mathrm{W}\right)$. Land masses include South Africa $\left(25^{\circ} \mathrm{E}\right)$, Australia $\left(135^{\circ} \mathrm{E}\right)$ and South America $\left(60^{\circ} \mathrm{W}\right)$ 


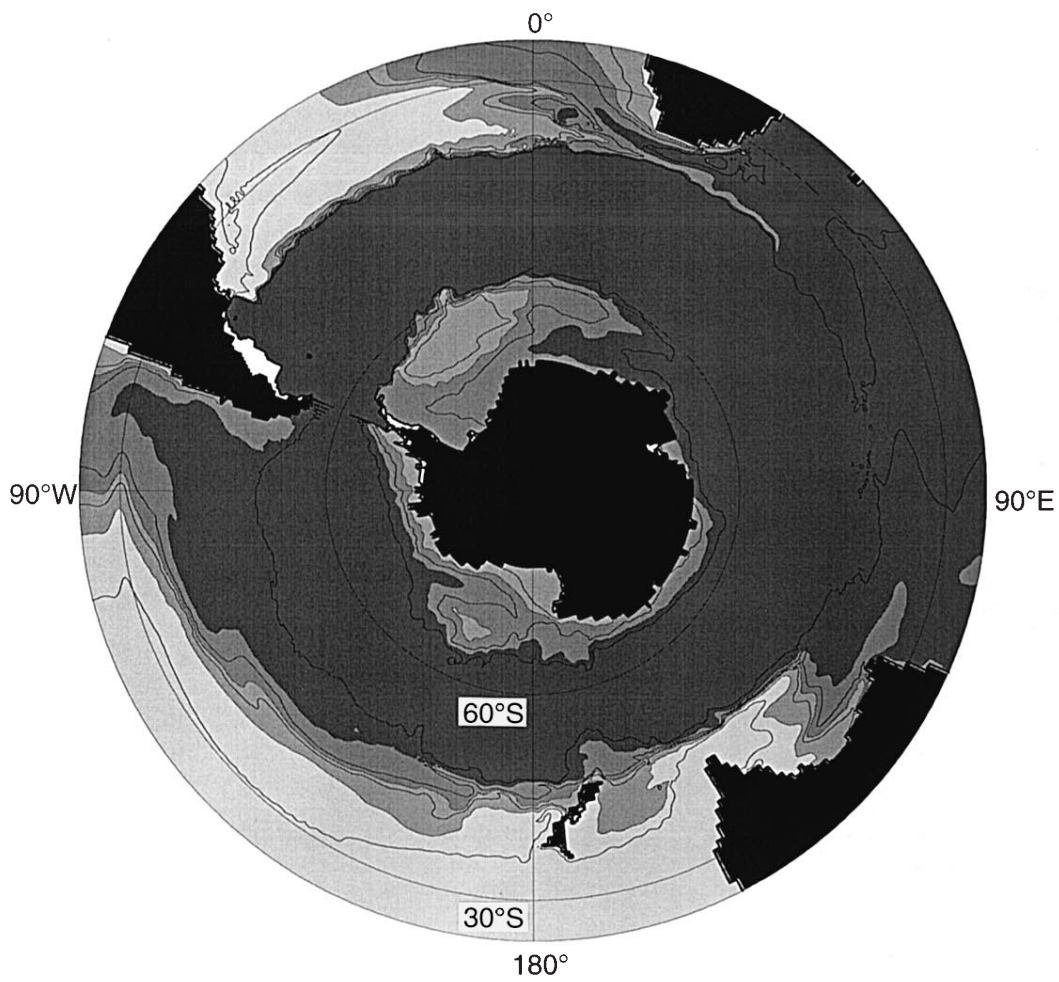

Tracer age (years)

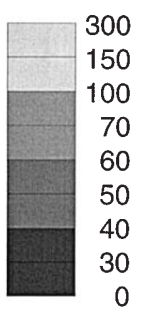

include water which has made less than or equal to one circuit around Antarctica. Multiple circuits in the ACC will result in overlap between areas and cannot be illustrated using this approach. A schematic diagram of the section at $20^{\circ} \mathrm{E}$ is shown in Fig. 10. The area denoted by ACC is water which has flowed through the Drake Passage. The exchange of waters between the
Atlantic and Indian Oceans are represented by $\mathrm{A} \rightarrow \mathrm{I}$ which is deep water of North Atlantic origin and has a transport of $10 \mathrm{~Sv}$ and $\mathrm{I} \rightarrow \mathrm{A}$ which is the Agulhas Current with a transport of $35 \mathrm{~Sv}$. The NADW is carried eastwards along with the ACC and enters the Indian Ocean by the Mozambique Channel and via the Crozet Basin, with the remainder continuing westwards

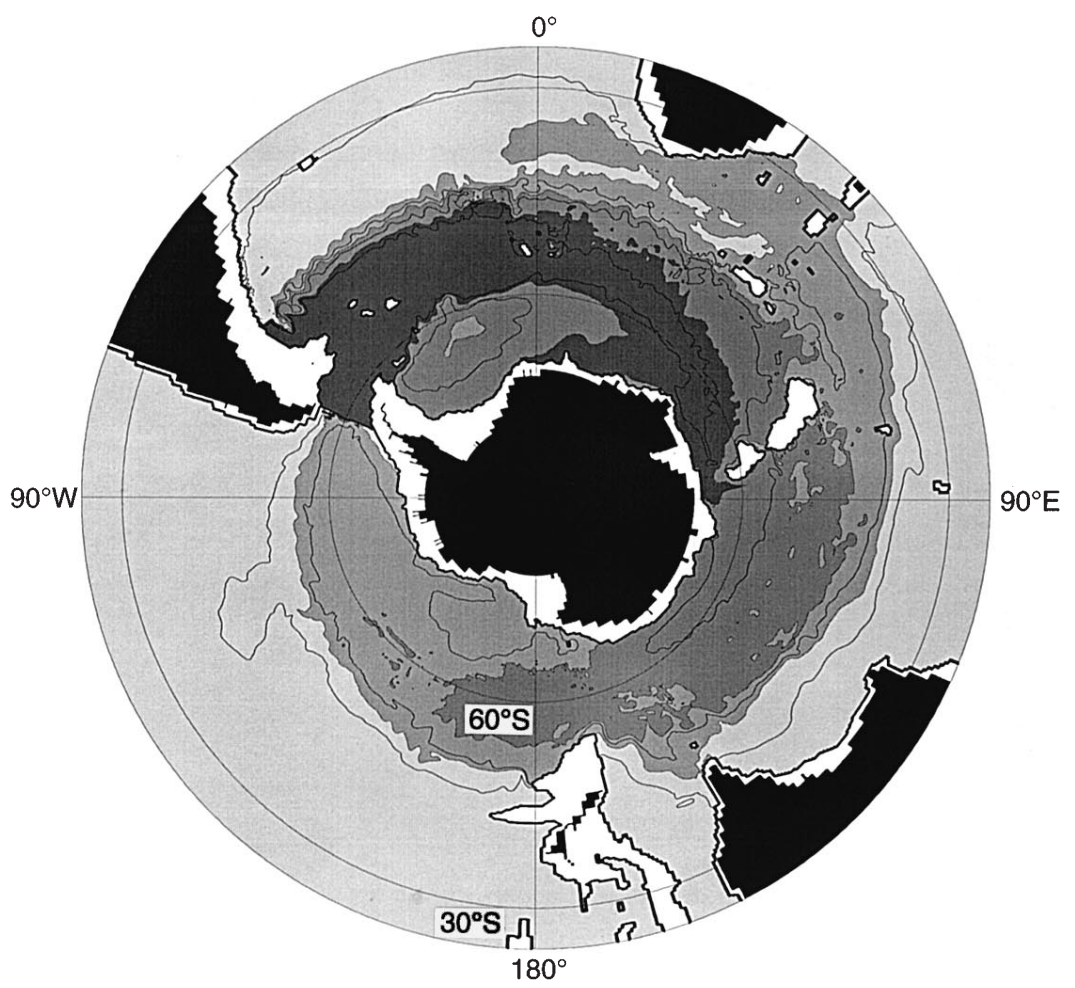

Tracer age (years)

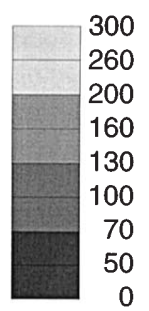

Fig. 8. A horizontal section
at $120 \mathrm{~m}$ illustrating the age of
tracer introduced at the Drake
Passage $\left(71^{\circ} \mathrm{W}\right)$

Fig. 8. A horizontal section
at $120 \mathrm{~m}$ illustrating the age of
tracer introduced at the Drake
Passage $\left(71^{\circ} \mathrm{W}\right)$

Fig. 8. A horizontal section
at $120 \mathrm{~m}$ illustrating the age of
tracer introduced at the Drake
Passage $\left(71^{\circ} \mathbf{W}\right)$ 


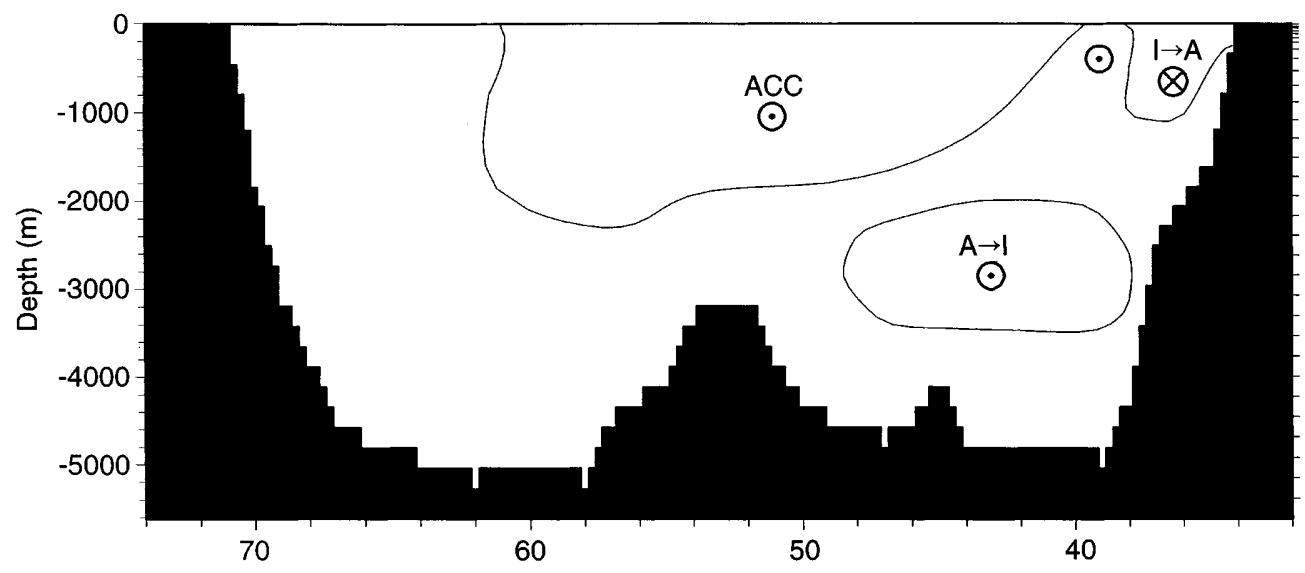

Fig. 10. A schematic meridional section along $20^{\circ} \mathrm{E}$ between Antarctica at $72^{\circ} \mathrm{S}$ and South Africa at $33^{\circ} \mathrm{S}$. The arrowhead and arrowtail symbols indicate water flowing eastwards and westwards respectively

Latitude $\left({ }^{\circ} \mathrm{S}\right)$

towards the Pacific Ocean. The isolated arrowhead at $39^{\circ} \mathrm{S}$ and a depth of $400 \mathrm{~m}$ is a narrow jet which derives from the Brazil current and carries a transport of $2 \mathrm{~Sv}$.

The section at $146^{\circ} \mathrm{E}$ shown in Fig. 11 is somewhat more complicated. The area labelled $\mathrm{A} \rightarrow \mathrm{P}$ is NADW which has traversed the Indian Ocean and now has a transport of $8 \mathrm{~Sv}$. Comparison of Figs. 10 and 11 show that in doing so, this water has risen and moved south. Some of this water enters the Pacific Ocean particularly just to the east of Australia and to a lesser extent to the east of the Tonga-Kermadec Ridge. The movement of water from the Indian Ocean to the Pacific Ocean at a depth of around $3000 \mathrm{~m}$ is labelled $\mathrm{I} \rightarrow \mathrm{P}$, and derives from a southwards flow to the west of Australia and has a transport of $2 \mathrm{~Sv}$. The source of this water is seen at $108^{\circ} \mathrm{E}$ in Fig. 5. The area labelled $\mathrm{I}+\mathrm{A} \rightarrow \mathrm{P}$ is derived from two sources. It comprises Indian Ocean tracer from the retroflection zone of the Agulhas Current and Atlantic Ocean tracer originating from the Brazil Current which has traversed the Indian Ocean and appears in Fig. 10 as the isolated arrowhead at $39^{\circ} \mathrm{S}$. By the time they reach the Pacific Ocean the two sources have mixed and occupy the same area on a meridional section. This water continues eastwards as a well-defined jet along the northern edge of the ACC and is easily traced through the Drake Passage. As noted earlier, some water from this source separates from the jet at $112^{\circ} \mathrm{W}$ and moves northwards into the Pacific Ocean above the crest of the East Pacific Rise.

The flow from the Pacific to Indian Ocean is labelled $\mathrm{P} \rightarrow \mathrm{I}$. This is a continuation of the East Australia Current moving westwards across the Great Australian Bight then separating from the coast and moving northwestwards into the Indian Ocean. This flow may form a minor part of the global "conveyor belt" and carries a transport of $4 \mathrm{~Sv}$, rather larger than the 1-2 Sv suggested by Semtner and Chervin (1992). This difference may also be a result of the lack of circulation around Australia which is of course allowed in their global ocean model, but prohibited by the open boundary condition in FRAM.

The section at $71^{\circ} \mathrm{W}$ is shown in Fig. 12. Atlantic Ocean tracer identified as NADW and labelled $\mathrm{A} \rightarrow \mathrm{A}$ passes eastwards through the Drake Passage at a mean depth of $1700 \mathrm{~m}$. This compares to a mean depth of $2600 \mathrm{~m}$ for NADW leaving the South American coast at $40^{\circ} \mathrm{S}$. This gradual upwards spiral of water circling Antarctica is indicated in Fig. $2 \mathrm{~b}$ and has also been described by Döös (1995).

Transport of water from the Pacific Ocean through the Drake Passage labelled $\mathrm{P} \rightarrow \mathrm{A}$, occurs at depths between $1000 \mathrm{~m}$ and $3000 \mathrm{~m}$ and is confined close to the

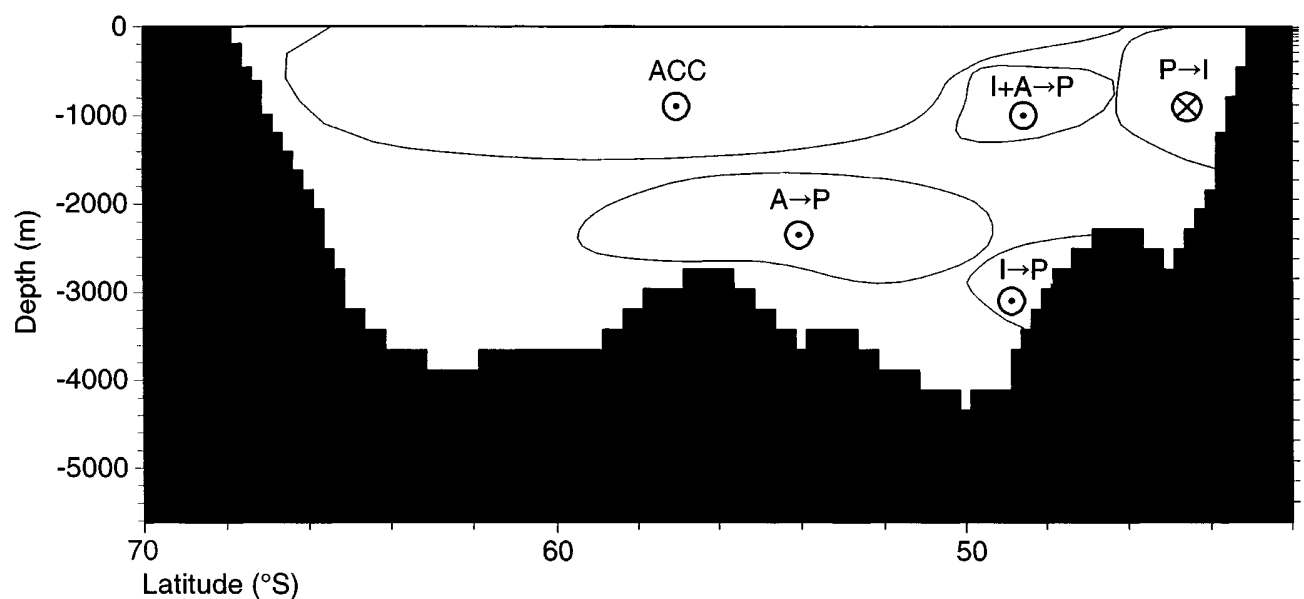

Latitude $\left({ }^{\circ} \mathrm{S}\right)$
Fig. 11. A schematic meridional section along $146^{\circ} \mathrm{E}$ between Antarctica at $69^{\circ} \mathrm{S}$ and Australia at $42^{\circ} \mathrm{S}$. The arrowhead and arrowtail symbols indicate water flowing eastwards and westwards respectively 


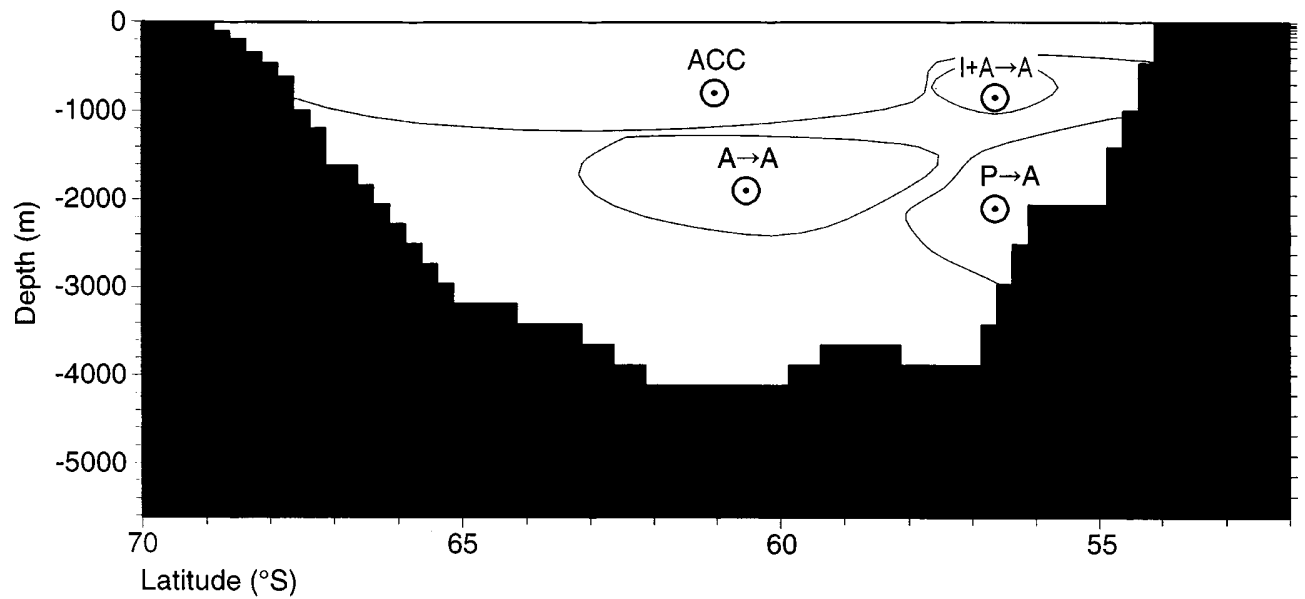

Fig. 12. A schematic meridional section along $71^{\circ} \mathrm{W}$ (Drake passage) between Antarctica at $69^{\circ} \mathrm{S}$ and South America at $53^{\circ} \mathrm{S}$. The arrowhead and arrowtail symbols indicate water flowing eastwards and westwards respectively north of the section. The water at depths between $1000 \mathrm{~m}$ and $1800 \mathrm{~m}$ is seen in Fig. 4 as originating from the separation of the East Australia Current from the Australian coast at $33^{\circ} \mathrm{S}$. The flow of Pacific Ocean tracer through the Drake Passage at depths between $1800 \mathrm{~m}$ and $2600 \mathrm{~m}$ can be traced back to the poleward flow of PDW which separates from the Campbell Plateau at $41^{\circ} \mathrm{S}$ and moves eastwards, crossing the East Pacific Rise at $50^{\circ} \mathrm{S}$. The transport associated with the strongest part of the flow is $6 \mathrm{~Sv}$. A section across the Drake Passage (Well, 1995) shows an area of high $\delta^{3} \mathrm{He}$ between $2000 \mathrm{~m}$ and $3000 \mathrm{~m}$ trapped against the northern boundary of the Drake Passage. The high values of $\delta^{3} \mathrm{He}$ are attributed to input of ${ }^{3} \mathrm{He}$ from hydrothermal vents in the East Pacific Rise (Jean-Baptiste et al., 1991). This is consistent with the path of PDW in FRAM which comes into contact with the crest of the East Pacific Rise at $50^{\circ} \mathrm{S}$ and traverses the Drake Passage in a similar area to the ${ }^{3} \mathrm{He}$ rich water observed by Well (1995). Tracer studies in the Atlantic sector of the Southern Ocean by Rüth et al. (1997) show sections of $\delta^{3} \mathrm{He}$ along $30^{\circ} \mathrm{W}$ and the Greenwich Meridian. Areas of high ${ }^{3} \mathrm{He}$ occur on both sections between $50^{\circ} \mathrm{S}$ and $55^{\circ} \mathrm{S}$ at depths between $1000 \mathrm{~m}$ and $2000 \mathrm{~m}$. These areas compare well with sections of tracer age for tracer originating from the Pacific Ocean.

The area in Fig. 12, labelled $\mathrm{I}+\mathrm{A} \rightarrow \mathrm{A}$ is a continuation of the area in Fig. 10 labelled $\mathrm{I}+\mathrm{A} \rightarrow \mathrm{P}$ which has crossed the Pacific Ocean as a narrow jet to the north of the ACC. The area labelled ACC is water which originated at the Drake Passage.

\section{Summary and conclusions}

Passive tracers have been introduced into a general circulation model of the Southern Ocean. The distribution of these tracers gives a description of the circulation which is generally in good agreement with observations.

The abyssal circulation of the Southern Ocean is not well reproduced in FRAM and this is attributed to a lack of seasonal forcing and poor representation of bottom water pathways due to smoothing of the topography. The open boundary conditions in FRAM performed well, however the geographical limits of the model produce unrealistic circulations in some areas, for example in the Mozambique Channel. Some features of the circulation such as the weak equatorward flow above the crest of the East Pacific Rise have not yet been observed.

The tracer distributions are consistent with the concept of a global "conveyor belt". The strength of the Aghulas Current and the path of near surface water from the Drake Passage to the Atlantic Ocean via the Indian Ocean gives support to both the modified cold water path and warm water paths for replenishment of NADW. It is difficult to quantify the importance of each route without an explicit representation of the Indonesian throughflow which would be obtained from a global model. The cold water path does exist in the model but is of minor importance.

We have demonstrated the usefulness of introducing passive tracers into ocean models, both to highlight particular features of the flow and also to build up an overall picture of the general circulation. The method is of greatest use in deriving a picture of the slow deep circulation and inter-basin exchange which is not easily obtained from inspection of the velocity field. Sections of tracers can also be useful in providing a contour within which to integrate a velocity component to obtain a transport although the transport estimates obtained must be treated with some caution. In that respect the method of Döös (1995) is better able to provide accurate transports and allows for multiple circuits of Antarctica. The method described here does however include the effect of convective mixing in a consistent way and also gives a better visual impression of the circulation than the particle trajectory approach of Döös.

Acknowledgements. The authors would like to thank John Johnson and other members of the FRAM group for helpful discussion, Russel Frew and Joachim Ribbe for pointing out sources of information and NERC for financial support under grant CST/02/ 408 (IGS)

Topical Editor D. J. Webb thanks P. Myers and M. England for their help in evaluating this paper. 


\section{References}

Banks, H., J. Bullister, S. Bacon, and H. Bryden, The Deep Western Boundary Current at $17^{\circ} \mathrm{S}$ in the Pacific Ocean, Int. WOCE Newsl., 19, 3-5, 1995.

Boland, F. M., and B. V. Hamon, Velocity measurements in the East Australia Current at $33^{\circ} \mathrm{S}$, Deep-Sea Res., 17, 777-794, 1970.

Cox, M. D., A primitive equation 3-dimensional model of the ocean, Geophys. Fluid Dyn. Lab. Ocean Group Tech. Rep., 1, 143 pp., 1984.

Cox, M. D., An idealised model of the World Ocean. Part I: the global scale water masses, J. Phys. Oceanogr., 19, 1730-1752, 1989.

Döös, K., Interocean exchange of water masses, J. Geophys. Res., 100, 13 499-13 514, 1995.

Döös, K., and A. C. Coward, The Southern Ocean as the major upwelling zone of North Atlantic Deep Water, Int. WOCE Newsl., 27, 3-6, 1997.

England, M. H., The age of water and ventilation time-scales in a global ocean model, J. Phys. Oceanogr., 25, 2756-2777, 1995a.

England, M. H., Using chlorofluorocarbons to assess ocean climate models, Geophys. Res. Lett., 22, 3051-3054, 1995 b.

Fine, R. A., Circulation of Antarctic Intermediate Water in the South Indian Ocean, Deep-Sea Res., 40, 2021-2042, 1993.

FRAM Group, Using an eddy resolving model to study the Southern Ocean. EOS, Trans. AGU, 72(15), 169, 174-175, 1991.

Gordon, A. L., Interocean exchange of thermocline water, J. Geophys. Res., 91, 5037-5046, 1986.

Gordon, A. L., R. F. Weiss, W. M. Smethie Jr. and M. J. Warner, Thermocline and Intermediate Water communication between the South Atlantic and Indian Oceans, J. Geophys. Res., 97, 7223-7240, 1992.

Hellerman, S., and M. Rosenstein, Normal monthly wind stress over the world ocean with error estimates, J. Phys. Oceanogr., 13, 1093-1104, 1983.

Jean-Baptiste, P., F. Mantisi, L. Memery, and D. Jamous, ${ }^{3} \mathrm{He}$ and chloroflourocarbons (CFC) in the Southern Ocean: tracers of water masses, Mar. Chem., 35, 137-150, 1991.

Levitus, S., Climatological Atlas of the World Ocean, NOAA Prof. Pap. 13, 173pp., US Government Print Office, Office Washington, D.C., 1982.

Lutjeharms, J. R. E., and D. J. Webb, Modelling the Agulhas Current system with FRAM (Fine Resolution Antarctic Model), Deep Sea Res., Part 1, 42, 523-551, 1995.

Mantayla, A. W., and J. L. Reid, On the origins of deep and bottom waters of the Indian Ocean, J. Geophys. Res., 100, 24172439, 1995.

Measures, C. I., and J. M. Edmond, Aluminium in the South Atlantic: steady state distribution of a short residence time element, J. Geophys. Res., 95, 5331-5340, 1990.

Mulhearn, P. J., Variability of the East Australia Current over most of its depth and comparison with other regions, J. Geophys. Res., 93, 13 925-13 929, 1988.

Mulhearn, P. J., J. H. Filloux, F. E. M. Lilley, N. L. Bindoff, and I. J. Ferguson, Abyssal currents during the formation and passage of a warm-core ring in the East Australia Current. Deep-Sea Res., 33A, 1563-1576, 1986.

Reid, J. L., W. D. Nowlin Jr., and W. C. Patzert, On the characteristics and circulation of the Southwestern Atlantic Ocean, J. Phys. Oceanogr., 7, 62-91, 1977.

Ribbe, J., and M. Tomezak, On convection and the formation of subantarctic mode Water in the Fine Resolution Antarctic Model (FRAM), J. Mar. Syst., 13, 137-154, 1997.

Rintoul, S. R., South Atlantic interbasin exchange, J. Geophys. Res., 96, 2675-2692, 1991.

Rüth, C., J. Sültenfuß, H. Rose, A. Putzka, and W. Roether, Tracer studies in the Southern South Atlantic within WOCE, Int. WOCE Newsl., 29, 11-13, 1997.

Sarmiento, J. L., A simulation of bomb tritium entry into the Atlantic Ocean, J. Phys. Oceanogr., 13, 1924-1939, 1983.

Saunders, P. M., and S. R. Thompson, Transport, heat and freshwater fluxes within a diagnostic numerical model (FRAM), J. Phys. Oceanogr., 23, 452-464, 1993.

Semtner, A. J., and R. M. Chervin, Ocean general circulation from a global eddy-resolving model, J. Geophys. Res., 97, 5493-5550, 1992.

Siedler, G., W. Balzer, T. J. Muller, R. Onken, M. Rhein, and W. Zenk, WOCE South Atlantic 1992, Cruise No 22, 22 September 1992- 31 January 1993, METEOR-Ber., Universität Hamburg, 93-5, 131 pp.

Stevens, D. P., The open boundary condition in the United Kingdom Fine-Resolution Antarctic Model, J. Phys. Oceanogr., 21, 1494-1499, 1991.

Stevens, D. P., and P. D. Killworth, The distribution of kinetic energy in the Southern Ocean: a comparison between observations and an eddy-resolving general circulation model, Philos. Trans. R. Soc. London B, 338, 251-257, 1992.

Stocker, T. F., D. G. Wright, and W. S. Broecker, The influence of high latitude surface forcing on the global thermohaline circulation, Paleoceanography, 7, 529-541, 1992.

Stommel, H., E. D. Stroup, J. L. Reid, and B. A. Warren, Transpacific hydrographic sections at Lats. $43^{\circ} \mathrm{S}$ and $38^{\circ} \mathrm{S}$; The Scorpio Expedition-I. Preface, Deep-Sea Res., 20, 1-7, 1973.

Thiele, G., and J. L. Sarmiento, Tracer dating and ocean ventilation, J. Geophys. Res., 95, 9377-9391, 1990.

Toggweiler, J. R., K. Dixon, and K. Bryan, Simulations of radiocarbon in a coarse resolution world ocean model. I: steady state prebomb distributions, J. Geophys. Res., 94, 8217-8242, 1989.

Wadley, M. R., and G. R. Bigg, Interbasin exchange of bottom water in ocean general circulation models, J. Phys. Oceanogr., 24, 2209-2214, 1994.

Warren, B.A., Deep western boundary current in the eastern Indian Ocean, Science, 196, 53-54, 1977.

Webb, D. J., P. D. Killworth, A. C. Coward, and S. R. Thompson, The FRAM Atlas of the Southern Ocean, Natural Environment Research Council, Swindon, UK, 1991.

Well, R., Analyse der Messguete eines massenspektrometrischen Messystems zur Heliumisotopen und Neon-Bestimmung von Meerwasserproben. PhD Thesis, Bremen University, December, 1995. 